\title{
Protective Effects of Broccoli (Brassica oleracea) and Its Active Components against Radical-Induced Oxidative Damage
}

\author{
Xiang Lan Pia0 ${ }^{1}$, Hyun Young KIM ${ }^{1}$, Takako YoKOZAWA ${ }^{2}$, \\ Young A LEE ${ }^{3}$, Xiang Shu PIAO ${ }^{4}$ and Eun Ju CHO ${ }^{3, *}$ \\ ${ }^{1}$ College of Pharmacy, Seoul National University, Seoul 151-742, Korea \\ ${ }^{2}$ Institute of Natural Medicine, Toyama Medical and Pharmaceutical University, \\ 2630 Sugitani, Toyama 930-0194, Japan \\ ${ }^{3}$ Department of Food Science and Nutrition, Pusan National University, \\ 30 Jangjeon-dong, Geumjeong-gu, Pusan 609-735, Korea \\ ${ }^{4}$ College of Animal Science and Technology, China Agriculture University, MAFIC, Beijing 100094, China
}

(Received May 31, 2004)

\begin{abstract}
Summary The radical scavenging effect and protective potential from oxidative damage by radical generator, 2,2'-azobis (2-amidinopropane) dihydrochloride (AAPH), in renal epithelial LLC-PK 1 cell of broccoli (Brassica oleracea) were investigated and identified the active components under the bioassay-linked fractionation method. The $\mathrm{MeOH}$ extract, and fractions of $\mathrm{CH}_{2} \mathrm{Cl}_{2}, \mathrm{BuOH}$ and $\mathrm{H}_{2} \mathrm{O}$ from broccoli showed the 1,1-diphenyl-2-picrylhydrazyl (DPPH) radical scavenging effect in a dose-dependent manner. In addition, they exerted the

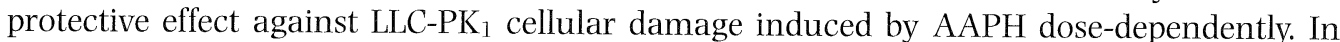
particular, the $\mathrm{BuOH}$ fraction was evaluated as the most active fraction, indicating that the $\mathrm{BuOH}$ fraction contains the active components with antioxidative capacity. Employing a bioassay-linked fractionation method, the active principles were isolated and characterized as 1,2-disinapoylgentiobiose and 1-sinapoyl-2-feruloylgentiobiose from the $\mathrm{BuOH}$ fraction. These two compounds from broccoli displayed potent antioxidant effects against the DPPH radical, showing the $\mathrm{IC}_{50}$ values of 5.18 and $7.52 \mu \mathrm{g} / \mathrm{mL}$, respectively. Moreover, the compounds significantly and dose-dependently recovered cell viability lowered by AAPH treatment, suggesting the protective roles from cellular oxidative damage. The present study suggests that broccoli has excellent antioxidative potential and the hydroxycinamic acid esters from broccoli, 1,2-disinapoylgentiobiose and 1-sinapoyl-2-feruloylgentiobiose, are considered as the active components with antioxidative effect.
\end{abstract}

Key Words broccoli, antioxidative activity, 1,2-disinapoylgentiobiose, 1-sinapoyl-2-feruloylgentiobiose

Free radicals and other reactive species are considered to be important causative factors in the development of various diseases and the aging process (1-4). This relationship has led to considerable interest in the search for antioxidants to scavenge free radicals and elevate the defense system. Although several synthetic antioxidants have been suggested for the prevention and treatment of diseases, various side effects and toxicities have become an issue. Therefore, the natural antioxidants from foods have attracted much attention and great effort has been made to search for safe and effective therapeutic agents for oxidative stress-related diseases.

Compelling evidence indicates that increased consumption of dietary antioxidants or vegetables with antioxidant properties may contribute to the improvement of the quality of life by delaying onset and reducing the risk of degenerative diseases (5-7). Epidemiological studies have shown that increased consumption of

\footnotetext{
${ }^{*}$ Corresponding author.

E-mail: ejcho@pusan.ac.kr
}

fruits and vegetables containing high levels of phytochemicals has been recommended to prevent chronic diseases related to oxidative stress in the human body $(8-11)$. In particular, a diet rich in cruciferous vegetables, such as broccoli, cabbage, brussels sprouts, cauliflower and kale, can reduce the risk from chronic degenerative diseases $(12,13)$. However, the antioxidative activities of these vegetables and the components with activity have not been clearly demonstrated.

Therefore, we investigated the free radical scavenging effect and antioxidative capacity of vegetables under in vitro and cellular models of oxidative stress (data not shown), and broccoli (Brassica oleracea) among them has been evaluated as the one with excellent antioxidative potential. Broccoli naturally contains many antioxidants, including carotenoids, tocopherol, ascorbic acid and flavonoids $(14,15)$; thus the antioxidative activity has been suggested. Therefore, the present study was focused on the radical scavenging effect of broccoli under in vitro and cellular system, and the active components of broccoli have been identified using the bioassay-linked fractionation method and the antioxidative 
activity verified.

\section{MATERIALS AND METHODS}

Materials. Broccoli was purchased at a market in Korea. 1,1-Diphenyl-2-picrylhydrazyl (DPPH) and 2,2'azobis (2-amidinopropane) dihydrochloride (AAPH) were obtained from Wako Pure Chemical Industries, Ltd. (Osaka, Japan). 3-(4,5-Dimethyl-2-thiazolyl)-2,5diphenyl-2H tetrazolium bromide (MTT) was purchased from Amresco (Solon, Ohio, USA). The LLC-PK 1 cell, a porcine renal epithelial cell, was provided by ATCC (Manassas, VA, USA). Dulbecco's modified Eagle medium/nutrient mixture F-12 (DMEM/F-12) and fetal bovine serum (FBS) were purchased from Invitrogen Co. (Grand Island, NY). NMR spectra were measured on a Bruker Avance 500 spectrometer (Bruker, Ettlingen, Germany, $500 \mathrm{MHz}$ for ${ }^{1} \mathrm{H}$ ). The Fab-MS was recorded on a Jeol JMS-700 mass spectrometer (Jeol, Tokyo, Japan).

Extract preparation and fractions from broccoli. The dried broccoli $(570 \mathrm{~g}$ ) was refluxed with $\mathrm{MeOH}$ for $3 \mathrm{~h}$. The organic solvent was removed in a vacuum to give $20 \mathrm{~g}$ of $\mathrm{MeOH}$ extract. The $\mathrm{MeOH}$ extract was dissolved in water and further partitioned in succession with $\mathrm{H}_{2} \mathrm{O}, \mathrm{CH}_{2} \mathrm{Cl}_{2}$ and $n-\mathrm{BuOH}$, affording 8.4, 4.5 and $5.5 \mathrm{~g}$ of the respective fractions.

Bioactivity-guided fractionation and comparison of radical scavenging activity. From the $\mathrm{BuOH}$ fraction, activity-guided isolation by silica gel chromatography eluted with chloromethane-MeOH (gradient elution, $10: 1 \rightarrow$ $1: 1)$ gave 7 fractions, and the DPPH radical scavenging activity of the 7 fractions was measured and compared.

Isolation and identification of active components. The most active fraction among the 7 fractions, fraction 5 , was further purified by silica gel chromatography using an EtOAc-MeOH $(10: 1)$ system. The two major components were isolated and their chemical structures were characterized by spectroscopic techniques of mass and NMR. Compound I ( $5 \mathrm{mg}$ ) and II (6 mg) were identified as 1,2-disinapoylgentiobiose and 1-sinapoyl-2-feruloylgentiobiose, respectively (16), and their chemical structures are illustrated in Fig. 1.

(1) 1,2-Disinapoylgentiobiose: Yellow crystal $(\mathrm{MeOH})$, $\mathrm{C}_{34} \mathrm{H}_{42} \mathrm{O}_{19}, \mathrm{FAB}-\mathrm{MS} \mathrm{m} / \mathrm{z}: 777[\mathrm{M}+\mathrm{Na}]^{+},{ }^{1} \mathrm{H}-\mathrm{NMR}(500$ MHz, DMSO-d 6 ): $7.63\left(1 \mathrm{H}, \mathrm{d}, J=15.8 \mathrm{~Hz}, \mathrm{H}-7^{\prime}\right), 7.62$ $(1 \mathrm{H}, \mathrm{d}, \mathrm{J}=15.8, \mathrm{H}-7), 6.88\left(2 \mathrm{H}, \mathrm{s}, \mathrm{H}-2^{\prime}, 6^{\prime}\right), 6.85$ (2H, s, $\mathrm{H}-2,6), 6.40\left(1 \mathrm{H}, \mathrm{d}, J=15.8 \mathrm{~Hz}, \mathrm{H}-8^{\prime}\right), 6.32(1 \mathrm{H}, \mathrm{d}$, $J=15.8 \mathrm{~Hz}, \mathrm{H}-8), 3.85\left(3 \mathrm{H}, \mathrm{s}, \mathrm{OCH}_{3}{ }^{\prime}\right), 3.83$ (3H, s, $\left.\mathrm{OCH}_{3}{ }^{\prime}\right), 5.77(1 \mathrm{H}, \mathrm{d}, J=8.83 \mathrm{~Hz}$, glu-1), $5.08(1 \mathrm{H}$, dd, $J=8.8,8.8 \mathrm{~Hz}$, glu-2), $4.35\left(1 \mathrm{H}, \mathrm{d}, J=7.9 \mathrm{~Hz}\right.$, glu- $\left.1^{\prime}\right)$, 4.11 ( $1 \mathrm{H}, \mathrm{d}, J=10.2 \mathrm{~Hz}$, glu-6b), $3.20(1 \mathrm{H}, \mathrm{dd}, J=7.9$, $8.7 \mathrm{~Hz}$, glc- $\left.3^{\prime}\right), 3.12\left(1 \mathrm{H}, \mathrm{dd}, J=7.9,8.7 \mathrm{~Hz}\right.$, glc- $\left.2^{\prime}\right),{ }^{13} \mathrm{C}-$ NMR (125 MHz, DMSO-d 6 ): 165.0 (C-9'), 164.2 (C-9), 147.5 (C-3, 3', 5, 5'), 146.8 (C-7'), 145.5 (C-7), 138.3 (C-4'), 137. 9 (C-4), 123.6 (C-1), $123.5\left(\mathrm{C}-1^{\prime}\right), 114.1$ (C-8'), 113.1 (C-8), 106.1 (C-2', 6'), 105.5 (C-2, 6), 102.6 (glc-1'), 91.5 (glc-1), 76.5 (glc-5'), 76.2 (glc-5), 75.9 (glc-3'), 73.2 (glc-3), 72.9 (glc-2), 72.1 (glc-2'), 69.4 (glc-4'), 69.0 (glc-4), 67.2 (glc-6), 60.5 (glc-6'),

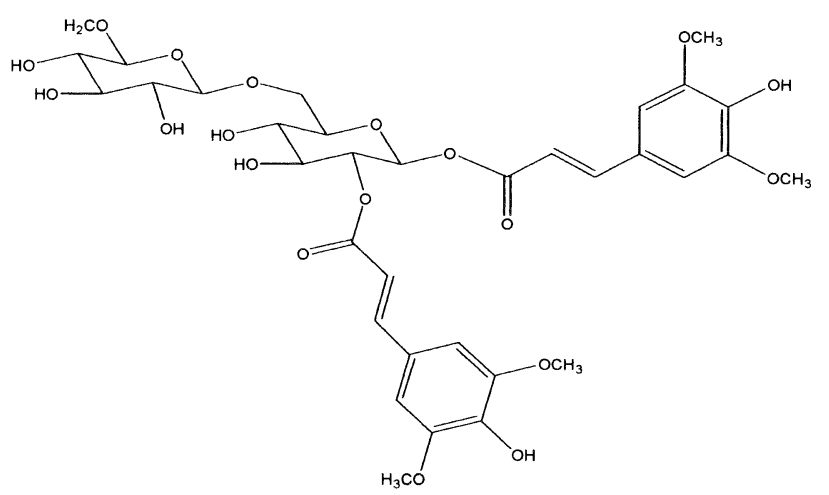

1,2-disinapoylgentiobiose

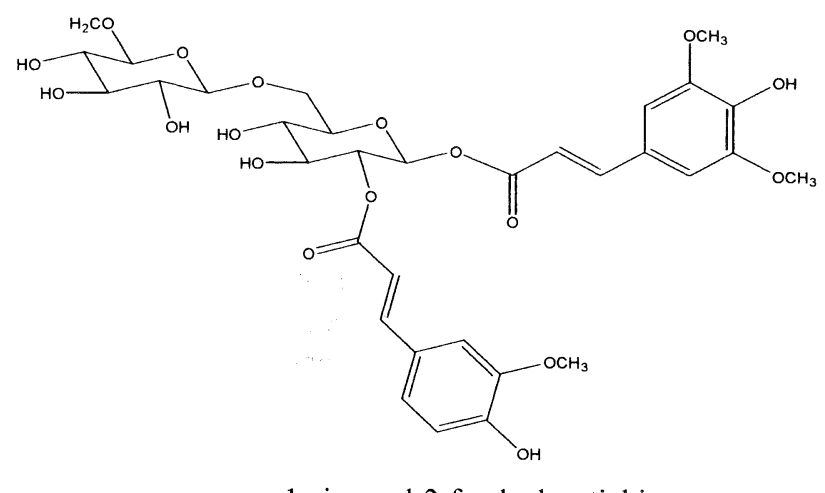

1-sinapoyl-2-feruloylgentiobiose

Fig. 1. Chemical structures of active components isolated from broccoli.

$55.6\left(\mathrm{OCH}_{3}^{\prime}\right), 55.5\left(\mathrm{OCH}_{3}\right)$.

(2) 1-Sinapoyl-2-feruloylgentiobiose: Yellow crystal $(\mathrm{MeOH}), \mathrm{C}_{33} \mathrm{H}_{40} \mathrm{O}_{18}$, FAB-MS m/z: $747[\mathrm{M}+\mathrm{Na}]^{+},{ }^{1} \mathrm{H}-$ NMR (500 MHz, DMSO-d 6 ): $7.62(1 \mathrm{H}, \mathrm{d}, J=15.8 \mathrm{~Hz}, \mathrm{H}-$ $\left.7^{\prime \prime \prime}\right), 7.60(1 \mathrm{H}, \mathrm{d}, J=15.8 \mathrm{~Hz}, \mathrm{H}-7), 7.30(1 \mathrm{H}, \mathrm{d}, J=2.0$ $\left.\mathrm{Hz}, \mathrm{H}-2^{\prime \prime \prime}\right), 7.09$ (1H, dd, J=2.0, 7.9 Hz, H-6"' ), 7.02 (2H, s, H-2, 6), 6.79 (1H, d, J=7.9 Hz, H-5"') 6.48 (1H, d, J=15.8 Hz, H-8), $6.48(1 \mathrm{H}, \mathrm{d}, J=15.8 \mathrm{~Hz}, \mathrm{H}-$ $\left.8^{\prime \prime \prime}\right), 3.84\left(3 \mathrm{H}, \mathrm{s}, \mathrm{OCH}_{3}{ }^{\prime}\right), 3.83\left(3 \mathrm{H}, \mathrm{s}, \mathrm{OCH}_{3}\right), 5.76(1 \mathrm{H}$, $\mathrm{d}, J=8.8 \mathrm{~Hz}$, glu-1), $4.92(1 \mathrm{H}, \mathrm{dd}, J=8.8,8.8 \mathrm{~Hz}$, glu2), $4.35(1 \mathrm{H}, \mathrm{d}, J=7.9 \mathrm{~Hz}$, glu-1'), $4.07(1 \mathrm{H}, \mathrm{d}$, $J=11.2 \mathrm{~Hz}$, glu-6b), $3.15(1 \mathrm{H}$, dd, $J=7.9,8.7 \mathrm{~Hz}$, glc$\left.3^{\prime}\right), 3.02\left(1 \mathrm{H}, \mathrm{dd}, J=7.9,8.7 \mathrm{~Hz}\right.$, glc- $\left.2^{\prime}\right),{ }^{13} \mathrm{C}-\mathrm{NMR}$ (125 MHz, DMSO-d ${ }_{6}$ ) d: 165.2 (C-9), 164.4 (C-9'), 148.8 (C-4'), 147.5 (C-3, 5), $147.4\left(\mathrm{C}-3^{\prime}\right), 146.8$ (C-7), $145.0\left(\mathrm{C}-7^{\prime}\right), 138.3(\mathrm{C}-4), 124.9\left(\mathrm{C}-1^{\prime}\right), 123.5(\mathrm{C}-1)$, 122.8 (C-6'), 114.9 (C-5'), 113.6 (C-8'), 113.1 (C-8), 110.6 (C-2'), 106.1 (C-6), 102.5 (glc-1'), 91.5 (glc-1), 76.5 (glc-5'), 76.2 (glc-5), 75.9 (glc-3'), 73.2 (glc-3), 72.8 (glc-2), 72.1 (glc-2'), 69.4 (glc-4'), 69.0 (glc-4), 67.2 (glc-6), 60.5 (glc-6' $), 55.6\left(\mathrm{OCH}_{3}\right), 55.0\left(\mathrm{OCH}_{3}{ }^{\prime}\right)$.

$\mathrm{DPPH}$ radical scavenging activity. One hundred microliters of an EtOH solution of the sample (the control used $100 \mu \mathrm{L}$ ethanol instead of the sample) was added to microwells followed by $100 \mu \mathrm{L}$ of $120 \mu \mathrm{M}$ DPPH in EtOH, according to the method of Hatano et al. (17). After gentle mixing and $30 \mathrm{~min}$ of standing at room temperature, the DPPH radical level was measured with a microplate reader, model SPECTRAmax 340PC (Molecular Devices, Sunnyvale, CA, USA). The 
antioxidant activity was expressed as the inhibition rate of the $\mathrm{DPPH}$ radical or the $\mathrm{IC}_{50}$ (concentration in $\mu \mathrm{g} /$ $\mathrm{mL}$ required to inhibit DPPH radical formation by $50 \%$ ) determined from the log-dose inhibition curve.

Experiment with cultured cells. Commercially available $\mathrm{LLC}_{\mathrm{PK}}$ cells were maintained at $37^{\circ} \mathrm{C}$ in a humidified atmosphere of $5 \% \mathrm{CO}_{2}$ in culture plates with $5 \%$ FBS-supplemented DMEM/F-12 medium. To investigate the protective activity from oxidative damage, we employed the AAPH-induced cellular oxidative model (18). After confluence had been reached, the cells were seeded into 96-well culture plates at $10^{4}$ cells per well. Two hours later, $1 \mathrm{mM}$ of AAPH was added to all of the wells, and then samples of extract, fractions or the compounds from broccoli were treated in the test wells. The plates were then incubated under routine conditions for $24 \mathrm{~h}$. The proper concentration of AAPH and the incubation time were determined by the preliminary experiment. Fifty microliters of MTT $(1 \mathrm{mg} / \mathrm{mL})$ solution was added to the each well. After incubation for $4 \mathrm{~h}$ at $37^{\circ} \mathrm{C}$, the MTT solution was removed from the medium. The resultant formazan crystals in the renal cells were solubilized with $100 \mu \mathrm{L}$ of dimethylsulfoxide. The absorbance of each well was then read at $540 \mathrm{~nm}$ using a microplate reader (model SPECTRAmax 340PC, Molecular Devices).

Statistical analysis. The results for each group were expressed as mean $\pm S D$ values. Data were analyzed by one way ANOVA between control and sample treated groups by SAS (SAS Institute Inc., Cary, NC, USA). Significant differences were determined among groups at $p<0.05$.

\section{RESULTS}

DPPH radical scavenging activity

As shown in Fig. 2, the extract of $\mathrm{MeOH}$, and fractions of $\mathrm{CH}_{2} \mathrm{Cl}_{2}, \mathrm{BuOH}$ and $\mathrm{H}_{2} \mathrm{O}$ from broccoli showed the DPPH radical scavenging effect in a dose-dependent manner. In particular, the $\mathrm{BuOH}$ fraction exerted the

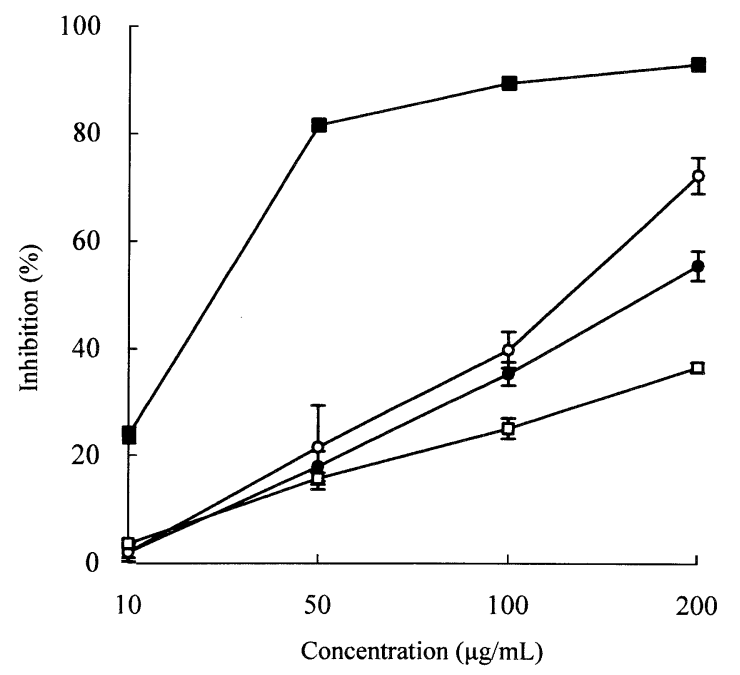

Fig. 2. Effect of $\mathrm{MeOH}$ extract (๑) and fractions of $\mathrm{CH}_{2} \mathrm{Cl}_{2}(\mathrm{O}), \mathrm{BuOH}(\boldsymbol{\square})$ and $\mathrm{H}_{2} \mathrm{O}(\square)$ from broccoli on $\mathrm{DPPH}$ radical.
Table 1. Effect of 7 fractions from $\mathrm{BuOH}$ fraction of broccoli on DPPH radical.

\begin{tabular}{|c|c|c|}
\hline $\begin{array}{l}\text { Fraction } \\
\text { No. }\end{array}$ & $\begin{array}{l}\text { Concentration } \\
(\mu \mathrm{g} / \mathrm{mL})\end{array}$ & $\begin{array}{c}\text { DPPH radical scavenging } \\
\text { activity }(\%)\end{array}$ \\
\hline \multirow[t]{4}{*}{1} & 10 & 0 \\
\hline & 25 & 0 \\
\hline & 50 & $5.96 \pm 0.22$ \\
\hline & 100 & $12.39 \pm 0.65$ \\
\hline \multirow[t]{4}{*}{2} & 10 & $1.83 \pm 0.43$ \\
\hline & 25 & $13.76 \pm 0.43$ \\
\hline & 50 & $20.18 \pm 1.30$ \\
\hline & 100 & $26.15 \pm 0.65$ \\
\hline \multirow[t]{4}{*}{3} & 10 & $0.92 \pm 0.43$ \\
\hline & 25 & $8.26 \pm 1.30$ \\
\hline & 50 & $16.97 \pm 0.65$ \\
\hline & 100 & $27.06 \pm 0.65$ \\
\hline \multirow[t]{4}{*}{4} & 10 & $1.38 \pm 0.65$ \\
\hline & 25 & $13.30 \pm 0.22$ \\
\hline & 50 & $25.23 \pm 0.22$ \\
\hline & 100 & $44.04 \pm 0.01$ \\
\hline \multirow[t]{4}{*}{5} & 10 & $2.75 \pm 0.01$ \\
\hline & 25 & $21.10 \pm 0.43$ \\
\hline & 50 & $46.33 \pm 1.51$ \\
\hline & 100 & $80.73 \pm 0.86$ \\
\hline \multirow[t]{4}{*}{6} & 10 & $2.29 \pm 1.08$ \\
\hline & 25 & $11.47 \pm 0.22$ \\
\hline & 50 & $21.10 \pm 0.01$ \\
\hline & 100 & $36.70 \pm 0.01$ \\
\hline \multirow[t]{4}{*}{7} & 10 & 0 \\
\hline & 25 & $2.29 \pm 0.65$ \\
\hline & 50 & $4.13 \pm 0.22$ \\
\hline & 100 & $31.19 \pm 0.43$ \\
\hline
\end{tabular}

strongest inhibition effect on DDPH radical generation, showing the inhibition of more than $80 \%$ at $50 \mu \mathrm{g} / \mathrm{mL}$ and almost $90 \%$ at $100 \mu \mathrm{g} / \mathrm{mL}$. In addition, Table 1 shows the result of DPPH radical scavenging activity linked with fractionation. Among the 7 fractions from the $\mathrm{BuOH}$ fraction of broccoli, fraction 5 exerted the strongest activity, showing 46 and $81 \%$ of DPPH radical scavenging activities at concentrations of 50 and $100 \mu \mathrm{g} / \mathrm{mL}$, respectively. On the other hand, other fractions showed relatively low DPPH radical scavenging activities.

Protective effect from $L L C-P K_{1}$ cellular damage induced by $A A P H$

Figure 3 shows the protective activity of extract and fractions from broccoli against AAPH-induced cellular damage. The treatment of AAPH resulted in the decrease of $\mathrm{LLC}^{\mathrm{P} \mathrm{PK}_{1}}$ cell viability to $61.3 \%$ compared with $100 \%$ of AAPH-non treated normal cells. On the other hand, the $\mathrm{MeOH}$ extract and fractions of $\mathrm{CH}_{2} \mathrm{Cl}_{2}$, $\mathrm{BuOH}$ and $\mathrm{H}_{2} \mathrm{O}$ elevated the cell viability significantly. In particular, the $\mathrm{BuOH}$ fraction recovered cell viability 


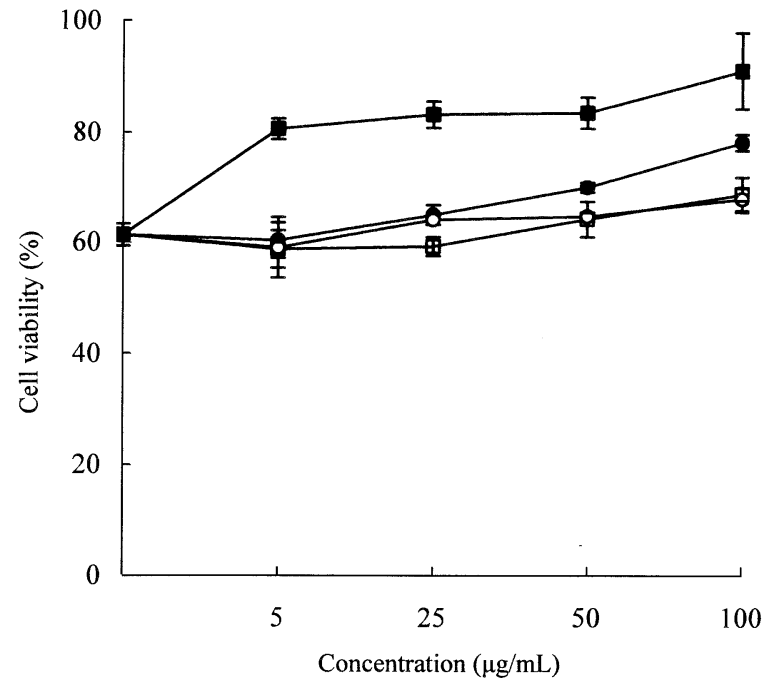

Fig. 3. Effect of $\mathrm{MeOH}$ extract $(\bullet)$ and fractions of $\mathrm{CH}_{2} \mathrm{Cl}_{2}(\mathrm{O})$, $\mathrm{BuOH}(\boldsymbol{\square})$ and $\mathrm{H}_{2} \mathrm{O}(\square)$ from broccoli on viability of $\mathrm{LLC}_{-\mathrm{PK}}$ cells treated with AAPH.

to $80 \%$ even at the low concentration of $5 \mu \mathrm{g} / \mathrm{mL}$, and to more than $90 \%$ at $100 \mu \mathrm{g} / \mathrm{mL}$, so the $\mathrm{BuOH}$ fraction revealed the strongest protective activity.

Antioxidative effects of 1,2-disinapoylgentiobiose and 1sinapoyl-2-feruloylgentiobiose

The DPPH radical-scavenging effect of the active component of broccoli is shown in Table 2. The $\mathrm{IC}_{50}$ vales were 5.18 and $7.52 \mu \mathrm{g} / \mathrm{mL}$ of 1,2 -disinapoylgentiobiose and 1-sinapoyl-2-feruloylgentiobiose, respectively. In addition, as revealed in Table 3, 1,2-disinapoylgentiobiose and 1-sinapoyl-2-feruloylgentiobiose significantly and dose-dependently recovered the cell

Table 2. DPPH radical scavenging activity of active components from broccoli.

\begin{tabular}{lc}
\hline \multicolumn{1}{c}{ Compound } & $\mathrm{IC}_{50}(\mu \mathrm{g} / \mathrm{mL})$ \\
\hline 1,2-Disinapoylgentiobiose & $5.18 \pm 1.11$ \\
1-Sinapoyl-2-feruloylgentiobiose & $7.52 \pm 1.64$ \\
\hline
\end{tabular}

viability lowered by the treatment of AAPH. They increased the cell viability of AAPH treated control cells from $61.3 \%$ almost to $90 \%$ at $2.5 \mu \mathrm{g} / \mathrm{mL}$. Moreover, the treatment of 1,2-disinapoylgentiobiose and 1-sinapoyl2 -feruloylgentiobiose at the concentration of $10 \mu \mathrm{g} / \mathrm{mL}$ elevated the cell viability of $\mathrm{LLC}-\mathrm{PK}_{1}$ to nearly normal values.

\section{DISCUSSION}

As the negative relationship between antioxidative status and various pathological conditions has been clearly recognized $(5,6)$, interest has been focused on the health benefits derived from food with antioxidant activity. Biologically active compounds can be found in vegetables and may play a role in reducing the risk of degenerative diseases involved in oxidative stress (1921). In particular, broccoli is becoming increasingly popular as a potential source of biologically active dietary components including flavonol glycosides, hydroxycinnamic acids and sulfur-containing compounds such as glucosinolates. We investigated the radical scavenging effect and antioxidative potential of extract and fractions of broccoli, and identified its active components. The in vitro antioxidative effect has been evaluated as the scavenging activity of the DDPH radical, and antioxidative potential under the cellular system of oxidative stress from AAPH using $\mathrm{LLC}_{-} \mathrm{PK}_{1}$ renal tubular epithelial cells that are susceptible to oxidative stress has also been observed.

To study the reactions of free radicals biologically, a well-designed in vitro model system is required. Numerous factors induce oxidative stress, such as irradiation, redox decomposition by metal ions of hydroperoxides or hydrogen peroxide, and thermal decomposition of free radical initiators including peroxides, hyponitrites, and azo compounds. To generate free radicals at a known, constant and well-defined rate, thermal decomposition of free radical initiators is preferred. It has been suggested that this can be achieved by the use of AAPH, one of the hydrophilic azo compounds. AAPH generates free radicals at a constant and measurable rate by its thermal decomposition without biotransformation. The

Table 3. Effect of active components from broccoli on viability of LLC-PK 1 cells treated with AAPH.

\begin{tabular}{ccc}
\hline & \multicolumn{2}{c}{ Cell viability $(\%)$} \\
\cline { 2 - 3 } Treatment $(\mu \mathrm{g} / \mathrm{mL})$ & 1-2-Disinapoylgentiobiose & $61.3 \pm 3.6^{\mathrm{a}}$ \\
\hline \multirow{2}{*}{ AAPH-treated control } & $61.3 \pm 3.6^{\mathrm{a}}$ & $72.5 \pm 1.3^{\mathrm{b}}$ \\
& $79.0 \pm 4.5^{\mathrm{b}}$ & $79.4 \pm 2.8^{\mathrm{c}}$ \\
1 & $86.9 \pm 3.1^{\mathrm{c}}$ & $88.0 \pm 1.7^{\mathrm{d}}$ \\
2.5 & $89.3 \pm 2.5^{\mathrm{c}}$ & $89.1 \pm 1.7^{\mathrm{d}}$ \\
5 & $96.9 \pm 0.9^{\mathrm{d}}$ & $96.6 \pm 3.4^{\mathrm{e}}$ \\
\hline 0 & $100.2 \pm 2.5^{\mathrm{d}}$ & \\
\hline
\end{tabular}

Means with the different letters are significantly different $(p<0.05)$ according to Duncan's multiple range test. 
free radicals generated from AAPH react with oxygen molecules rapidly to yield peroxyl radicals. The lipid peroxyl radicals attack other lipid radicals. This reaction takes place repeatedly with resultant attacks upon various biological molecules, and induces physiochemical alterations and cellular damage (22). Finally, AAPH causes a diverse array of pathological changes. Therefore, an AAPH-intoxication experiment may be a promising assay system for the biological activities of antioxidants. In an appropriate model system, hydrophilic antioxidants can be used to scavenge radicals and suppress the oxidation initiated by AAPH within cells (23, 24). In addition, AAPH administration results in the in vivo damage of biological tissues such as lymphocytes, kidney and liver, leading to pathological conditions including atherosclerosis, ischemia-reoxygenation injury, and inflammatory disease.

The present study also supports that AAPH leads to the decreased viability of $\mathrm{LLC}_{-} \mathrm{PK}_{1}$ renal epithelial cells. Consistent with this result, several reports have documented that AAPH decreased the viability of hepatic cells, neuron and aortic endothelial cells and the treatment with AAPH induced apoptosis in the cells, causing loss of viability (25-27). On the other hand, this study demonstrated that the extract and fractions of broccoli exerted the DPPH radical scavenging effect; in addition, the oxidative damage to LLC-PK 1 cells by AAPH has been recovered with the treatment of broccoli, resulting in the increase of cell viability in a significant and dose dependent manner. In particular, the in vitro and cellular oxidative damage system showed that the $\mathrm{BuOH}$ fraction has the strongest activity against free radical generation and oxidative damage. The application of broccoli extract or fractions to LLC-PK 1 cells damaged by AAPH recovered cellular loss caused by peroxyl radicals from AAPH, suggesting that the compounds in broccoli, especially in those from the $\mathrm{BuOH}$ fraction, may play a vital role in the protection from oxidative damage from AAPH. Furthermore, the bioassay-linked fractionation method identified the compounds with activity as 1,2-disinapoylgentiobiose and 1-sinapoyl-2-feruloylgentiobiose.

Cruciferous vegetables including broccoli contain several classes of compounds that can potentially contribute to antioxidant activity including vitamins, phenols and glucosinolates. Plumb et al. (28) reported that the glucosinolates in cruciferous vegetables including broccoli are unlikely to account for the direct antioxidant effects of cruciferous vegetables. They also suggest that the antioxidant activity of the extracts probably involves the hydroxylated phenol and polyphenol content of cruciferous vegetables, so the excellent antioxidative potential may be attributed to the large amounts of quercetin and kaempferol in broccoli. In the addition to these reports, the present study clearly demonstrates that 1,2-disinapoylgentiobiose and 1-sinapoyl-2-feruloylgentiobiose are also mainly responsible for the radical scavenging effect and protective activity from oxidative damage. These two compounds from broccoli have been reported (15), but their antioxidative capacities under a cellular damage model have been first suggested in the present study.

The implication of hydroxycinnamic acids in the diet is receiving much interest and they have been considered as the biologically active compounds; however, the evidence has not been clearly supported. Of the biological activities, the antitumor or anticancer activity of hydroxycinnamic acid esters such as ferulic acid has been suggested (29-31). On the other hand, the radical scavenging activity and protective effect from peroxyl radicals of 1,2-disinapoylgentiobiose and 1-sinapoyl-2feruloylgentiobiose have not been reported yet, and other promising potentials have not been studied.

We could also hypothesize that some portion of the compounds are not absorbed in the small intestine, and these pass into the colon where they are broken down by gut microbes on the basis of the reported evidence on the metabolism of flavonoid glycosides in vivo $(32,33)$. Further study is needed to verify the uptake and absorption, and the metabolism in animals or humans.

\section{Acknowledgments}

This work was supported by a Korean Research Foundation Grant (KRF-2004-003-F00044).

\section{REFERENCES}

1) Yu BP, Chung HY. 2001. Oxidative stress and vascular aging. Diabetes Res Clin Pract 54: S73-S80.

2) Maxwell SR. 2000. Coronary artery disease-free radical damage, antioxidant protection and the role of homocystein. Basic Res Cardiol 95: I/65-I/71.

3) Ray G, Batra S, Shukla NK, Deo S, Raina V, Ashok S, Husain SA. 2000. Lipid peroxidation, free radical production and antioxidant status in breast cancer. Breast Cancer Res Treat 59: 163-170.

4) Butterfield DA, Lauderback CM. 2002. Lipid peroxidation and protein oxidation in Alzheimer's disease brain: potential causes and consequences involving amyloid $\beta$ peptide-associated free radical oxidative stress. Free Radic Biol Med 32: 1050-1060.

5) Meydani M, Lipman RD, Han SN, Wu D, Beharka A, Martin KR, Bronson R, Cao G, Smith D, Meydani SN. 1998. The effect of long-term dietary supplementation with antioxidants. Ann NY Acad Sci 854: 352-360.

6) Ames BN, Shigenaga MK, Hagen TM. 1993. Oxidants, antioxidants, and the degenerative disease of aging. Proc Natl Acad Sci USA 90: 7915-7922.

7) Steinmetz KA, Potter JD. 1996. Vegetables, fruits, and cancer prevention. J Am Diet Assoc 96: 1027-1039.

8) Chu YF, Sun J, Wu X, Liu RH. 2002. Antioxidant and antiproliferative activities of common vegetables. J Agric Food Chem 50: 6910-6916.

9) Liu RH. 2003. Health benefits of fruit and vegetables are from additive and synergistic combinations of phytochemicals. Am J Clin Nutr 78: 517S-520S.

10) Rimm EB, Ascherio A, Giovannucci E, Spiegelman D, Stampfer MJ, Willett WC. 1996. Vegetable, fruit, and cereal fiber intake and risk of coronary heart disease among men. JAMA 275: 447-451.

11) Gillman MW, Cupples LA, Gagnon D, Posner BM, Ellison RC, Castelli WP, Wolf PA. 1995. Protective effect of fruits and vegetables on development of stroke in men. JAMA 273: 1113-1117. 
12) Graham S. 1983. Results of case-control studies of diet and cancer in Buffalo, New York. Cancer Res 43: 2409s2413s.

13) Bazzano LA, He J, Ogden LG, Loria CM, Vupputuri S, Myers L, Whelton PK. 2002. Fruit and vegetable intake and risk of cardiovascular disease in US adults: the first national health and nutrition examination survey epidemiologic follow-up study. Am J Clin Nutr 76: 93-99.

14) Kurilich AC, Tsau GJ, Brown A, Howard L, Klein BP, Jeffery EH, Kushad M, Wallig MA, Juvik JA. 1999. Carotene, tocopherol, and ascorbate contents in subspecies of Brassica oleracea. J Agric Food Chem 47: 1576-1581.

15) Plumb GW, Price KR, Rhodes MJ, Williamson G. 1997. Antioxidant properties of the major polyphenolic compounds in broccoli. Free Radic Res 27: 429-435.

16) Price KR, Casuscelli F, Colquhoun IJ, Rhodes MJC. 1997. Hydroxycinnamic acid esters from broccoli florets. Phytochemistry 45: 1683-1687.

17) Hatano T, Edamatsu R, Hiramatsu M, Mori A, Fujita Y, Yasuhara T, Yoshida T, Okuda T. 1989. Effects of the interaction of tannins with co-existing substances. VIz. Effects of tannins and related polyphenols on superoxide anion radical, and on 1,1-diphenyl-2-picrylhydrazyl radical. Chem Pharm Bull 37: 2016-2021.

18) Yokozawa T, Cho EJ, Hara Y, Kitani K. 2000. Antioxidative activity of green tea treated with radical initiator 2,2'-azobis(2-amidinopropane) dihydrochloride. J Agric Food Chem 48: 5068-5073.

19) Rice-Evans CA, Miller NJ, Bolwell PG, Bramley PM, Pridham JB. 1995. The relative antioxidant activities of plant-derived polyphenolic flavonoids. Free Radic Res 22: 375-383.

20) Giovannucci E. 1999. Tomatoes, tomato-based products, lycopene, and cancer: review of the epidemiologic literature. J Natl Cancer Inst 91: 317-331.

21) Knekt P, Jarvinen R, Reunanen A, Maatela J. 1996. Flavonoid intake and coronary mortality in Finland: a cohort study. BMJ 312: 478-481.

22) Miki M, Tamai H, Mino M, Yamamoto Y, Niki E. 1987. Free-radical chain oxidation of rat red blood cells by molecular oxygen and its inhibition by $\alpha$-tocopherol. Arch Biochem Biophys 258: 373-380.

23) Terao K, Niki E. 1986. Damage to biological tissues induced by radical initiator $2,2^{\prime}$-azobis (2-amidinopropane)dihydrochloride and its inhibition by chain-breaking antioxidants. Free Radic Biol Med 2: 193-201.
24) Dooley MM, Sano N, Kawashima H, Nakamura T. 1990. Effects of 2,2'-azobis(2-amidinopropane)hydrochloride in vivo and protection by vitamin E. Free Radic Biol Med 9: 199-204.

25) Matsura T, Yamada K, Kawasaki T. 1992. Difference in antioxidant activity between reduced coenzyme $Q 9$ and reduced coenzyme Q10 in the cell: studies with isolated rat and guinea pig hepatocytes treated with a water-soluble radical initiator. Biochim Biophys Acta 1123: 309315.

26) Rapin JR, Zaibi M, Drieu K. 1998. In vitro and in vivo effects of an extract of Ginkgo biloba (EGb 761), ginkgolide $\mathrm{B}$, and bilobalide on apoptosis in primary cultures of rat hippocampal neurons. Drug Dev Res 45: 23-29.

27) Martin A, Wu DY, Baur W, Meydani SN, Blumberg JB, Meydani M. 1996. Effect of vitamin E on human aortic endothelial cell responses to oxidative injury. Free Radic Biol Med 21: 505-511.

28) Plumb GW, Lambert N, Chambers SJ, Wanigatunga S, Heaney RK, Plumb JA, Aruoma OI, Halliwell B, Miller NJ, Williamson G. 1996. Are whole extracts and purified glucosinolates from cruciferous vegetables antioxidants? Free Radic Res 25: 75-86.

29) Ferguson LR, Lim IF, Pearson AE, Ralph J, Harris PJ. 2003. Bacterial antimutagenesis by hydroxycinnamic acids from plant cell walls. Mutat Res 542: 49-58.

30) Mori H, Kawabata K, Yoshimi N, Tanaka T, Murakami T, Okada T, Murai H. 1999. Chemopreventive effects of ferulic acid on oral and rice germ on large bowel carcinogenesis. Anticancer Res 19: 3775-3778.

31) Tanaka T, Kojima T, Kawamori T, Wang A, Suzui M, Okamoto K, Mori H. 1993. Inhibition of 4-nitroquinoline-1-oxide-induced rat tongue carcinogenesis by the naturally occurring plant phenolics caffeic, ellagic, chlorogenic and ferulic acids. Carcinogenesis 14: 13211325 .

32) Hollman PC, de Vries JH, van Leeuwen SD, Mengelers MJ, Katan MB. 1995. Absorption of dietary quercetin glycosides and quercetin in healthy ileostomy volunteers. Am J Clin Nutr 62: 1276-1282.

33) Yokozawa T, Kim HY, Cho EJ, Choi JS, Chung HY. 2002. Antioxidant effects of isorhamnetin 3,7-di-O- $\beta$-D-glucopyranoside isolated from mustard leaf (Brassica juncea) in rats with streptozotocin-induced diabetes. J Agric Food Chem 50: 5490-5495. 